PhDr. Jan Stejskal

Obranné plánování NATO (neustále) v tranzici

Vojenské rozhledy, 2013, roč. 22 (54), č. 3, s. 71-80, ISSN 1210-3292

\title{
NATO Defence Planning Process in (Permanent) Transition
}

\section{Abstrakt:}

Proces obranného plánování NATO (NDPP) prochází relativně častými revizemi a úpravami, aby odpovídal jak potřebám NATO jako celku, tak potrebám každého členského státu. Zatím poslední impulz $k$ dalši optimalizaci procesu vzešel z chicagského summitu v květnu 2012 - v tomto kontextu mluvíme o posílení či zlepšení NDPP (Enhancing NDPP). Hlavním cílem této iniciativy je posílení relevance a vlivu procesu NDPP na národní procesy plánování a zvýšení politické viditelnosti NDPP. Větši důraz klade i na včasné konzultace mezi spojenci, kdykoli zamýšlejí provádět významnější změny ve struktuře svých sil a schopností. Nedávno schválené cíle obranného plánování NATO (v červnu 2013), dřive známé jako Force Goals (cíle výstavby sil), jsou poprvé výrazně ovlivněny užitím tzv. ,zásady 50 \%“, která má přspět k nápravě nerovnoměrného sdílení bremene v poskytování schopností mezi USA a ostatními členy NATO.

\section{Abstract:}

The NATO Defence Planning Process (NDPP) is a subject of quite frequent reviews and amendments in order to meet the needs of NATO as an organization and of each Ally. The current initiative, based on a tasking from the Chicago summit in May 2012, is referred to as "Enhancing the NDPP". It particularly aims at making the NDPP more relevant to national defence planning and more visible at political level. More emphasis is also placed on timely consultations among Allies whenever they intend to make significant changes in their defence inventories and capabilities. Recently approved NATO Defence Planning Capability Targets (June 2013) previously known as Force Goals, are for the first time affected by application of the so-called " $50 \%$ planning assumption" which aims to redress the burden-sharing imbalance between the US and other Allies.

\section{Klíčová slova:}

Proces obranného plánování NATO, NDPP, zásada 50\%, minimální požadavky na schopnosti, MCR, sdílení břemene.

\section{Key words:}

NATO Defence Planning Process, NDPP, 50\% planning assumption, Minimum Capability Requirements, MCR, burden sharing. 
Pro plnění svých základních úkolů, tj. zejména pro případné vedení operací, potřebuje Severoatlantická aliance odpovídající škálu schopností. Odpověd’ na otázku, které schopnosti to jsou a v jakém množství jsou zapotřebí, poskytuje tzv. proces obranného plánování NATO (NDPP - NATO Defence Planning Process). Aby vyhovoval potřebám členských států i NATO jako organizaci, patří již k aliančnímu folklóru se čas od času nad NDPP koncepčně zamyslet a navrhnout opatření, jak tento proces zlepšit, posílit, a zvýšit hodnotu jeho výstupů. [1]

\section{Cíl}

Cílem tohoto příspěvku je poskytnout aktuální informaci o stavu a vývoji obranného plánování NATO. V současnosti probíhající cyklus je třeba vnímat především jako realizaci rozhodnutí zaměřených na celkovou optimalizaci plánovacího procesu přijatých v roce 2009. Avšak ještě před tím, než tento přechodový cyklus dospěje ke svému konci, byly iniciovány nové kroky, jejichž ambicí je další posílení kvality některých podstatných aspektů procesu. Také těmto novým podnětům a jejich pozadí se článek věnuje a nabízí určitá východiska k zamyšlení nad jejich dopadem na plánování rozvoje schopností jednotlivých členských států NATO a zvláště pak České republiky.

\section{NDPP - aktuální (přechodový) cyklus}

Proces NDPP je obecně navržen jako cyklus pěti na sebe navazujících kroků. Podle současného nastavení se jednotlivé cykly mají opakovat ve čtyřleté periodě. Některé kroky, konkrétně vyhodnocení plnění cílů, se však opakují každé dva roky. Fázi implementace cílů je z logiky věci třeba vnímat jako kontinuální, přecházející z jednoho cyklu do druhého.

Pět fází (kroků) NDPP:

1. Politická směrnice, zadání pro konkrétní plánovací cyklus (establish political guidance).

2. Stanovení celkových požadavků na schopnosti Aliance (determine requirements; Capability Requirements Review; Minimum Capability requirement).

3. Rozdělení požadavků mezi členské státy a jejich přidělení v podobě cílů obranného plánování (apportion requirements and set targets).

4. Implementace cílů (facilitate implementation).

5. Vyhodnocení, jakých schopností již spojenci dosáhli a jak plánují splnit své cíle (review results/Capability Review).

V jaké fázi se podle obecné architektury NDPP právě nacházíme? [2] Krátká odpověd' zní: Právě byl ukončen třetí krok, a zároveň již byl zahájen sběr informací v rámci pátého kroku. Rok 2013 patří do tzv. přechodového cyklu (transition cycle), během kterého by mělo být plně implementováno nastavení procesu NDPP schválené v dokumentu „Outline Model for a NATO Defence Planning Process“ z dubna 2009. [3]

Přechodový plánovací cyklus byl spuštěn politickou směrnicí z března 2011. [4] Ta byla mimo jiné zadáním pro stanovení minimálních požadavků na schopnosti - NATO Minimum Capability Requirements 2011 (MCR). Zpráva definující MCR byla schválena oběma strategickými veliteli 20. prosince 2011. [5] 


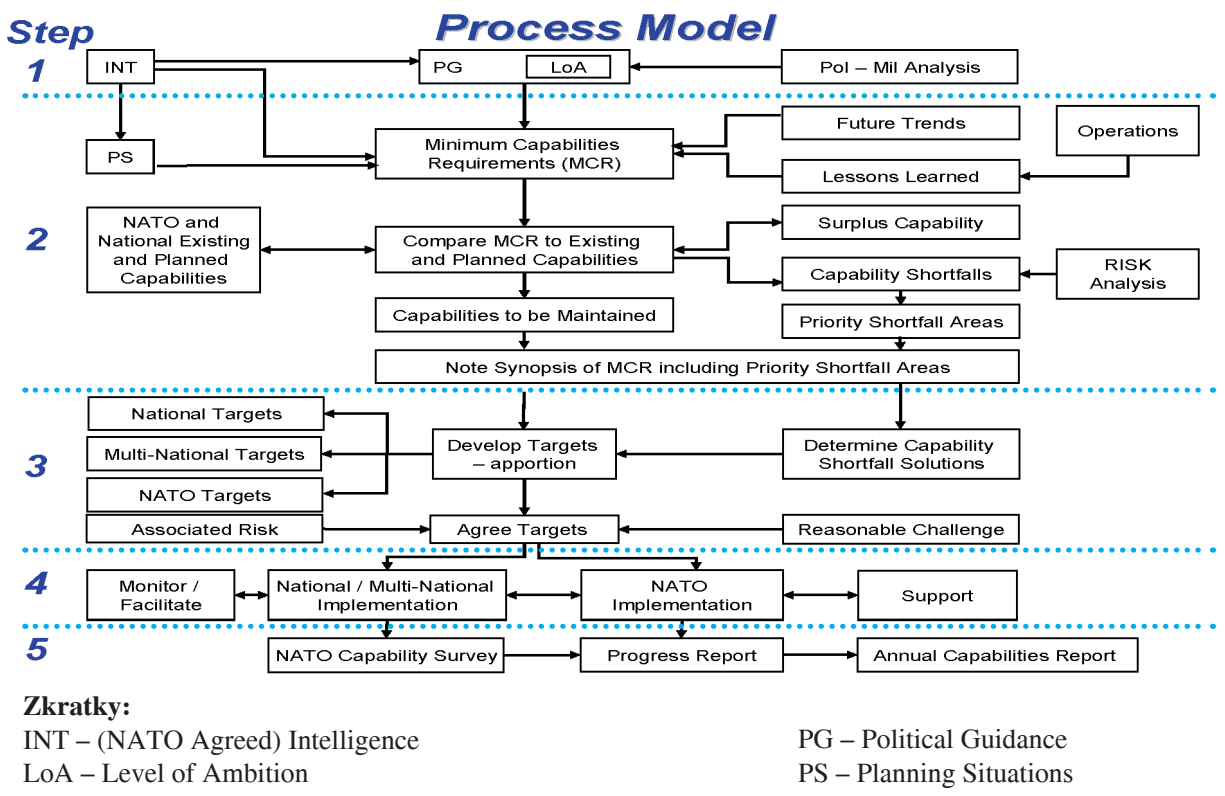

Obr.1: Schéma procesu NDPP v podobě schválené v dubnu 2009.

Spolu s těmito minimálními požadavky vojenské orgány NATO identifikovaly také prioritní oblasti nedostatků ve schopnostech - Priority Shortfall Areas 2012. Jejich shrnutí vzal DPPC - alianční výbor odpovědný za obranné plánování - na vědomí 14. zář́i 2012. [6]

Výsledkem rozdělení požadavků do cílů a jejich přidělení jednotlivým státům (tř̌etí fáze NDPP) jsou tzv. NATO Defence Planning Capability Targets 2013. Ministři obrany tyto cíle schválili při svém zasedání 4. června 2013, čímž se zároveň zavázali promítnout je do svých národních procesů obranného plánování. [7] Vzhledem k tomu, že nebyla včas vyjasněna úloha jednotlivých aliančních výborů při posouzení a dopracování kolektivních cílů, tedy cílů, které by měla implementovat Aliance jako celek (potenciálně s využitím společného financování), ministrům obrany tyto cíle v červnu 2013 ke schválení předloženy nebyly. Stane se tak až po posouzení kolektivních cílů v RPPB (Resource Policy and Planning Board) a poté v DPPC (Defence Policy and Planning Committee).

Dalším krokem v aktuálním cyklu NDPP bude zhodnocení, jak členské státy hodlajî své cíle implementovat. Tato fáze hodnocení (Capability Review) bude zahájena předložením národních odpovědí na NDPCS 2013 (NATO Defence Planning Capability Survey, dotazník obranného plánování). V plnění dotazníku a celý 5. krok NDPP se opakuje v dvouleté periodě, proto i v tomto roce byl termín pro předložení odpovědí na dotazník stanoven na 31. července.

Analýzou odpovědí se bude zabývat tým expertů NDPST (NATO Defence Planning Staff Team), který také připraví návrh hodnotící zprávy pro každý členský stát. S každou zemí bude návrh hodnocení jejích plánů projednán při bilaterálních konzultacích - obvykle v hlavních městech - během podzimu 2013. Na základě těchto jednání budou 
národní hodnocení dále upravena, aby na jaře 2014 proběhla série multilaterálních jednání v DPPC, při nichž si všechny státy svá hodnocení budou posuzovat navzájem. Výsledkem bude zpráva pro ministry obrany na jejich zasedání v červnu 2014 s hodnocením, do jaké míry lze očekávat naplnění ambicí Aliance a v jakém stavu se nacházejí její schopnosti a kapacity pro plnění jejích hlavních úkolů. Tuto zprávu bude doprovázet posouzení rizik, která vzhledem k dosažení aliančních ambicí vyplývají právě z daného stavu schopností a plánů k jejich výstavbě. Zhodnocení rizik připraví vojenský výbor na základě analýzy provedené oběma strategickými velitelstvími. Tímto krokem bude de facto také završen přechodový plánovací cyklus NDPP (pokrok ve výstavbě schopností a plnění aliančních cílů z roku 2013 bude vyhodnocen ještě jednou, závěry budou $\mathrm{k}$ dispozici na jaře 2016).

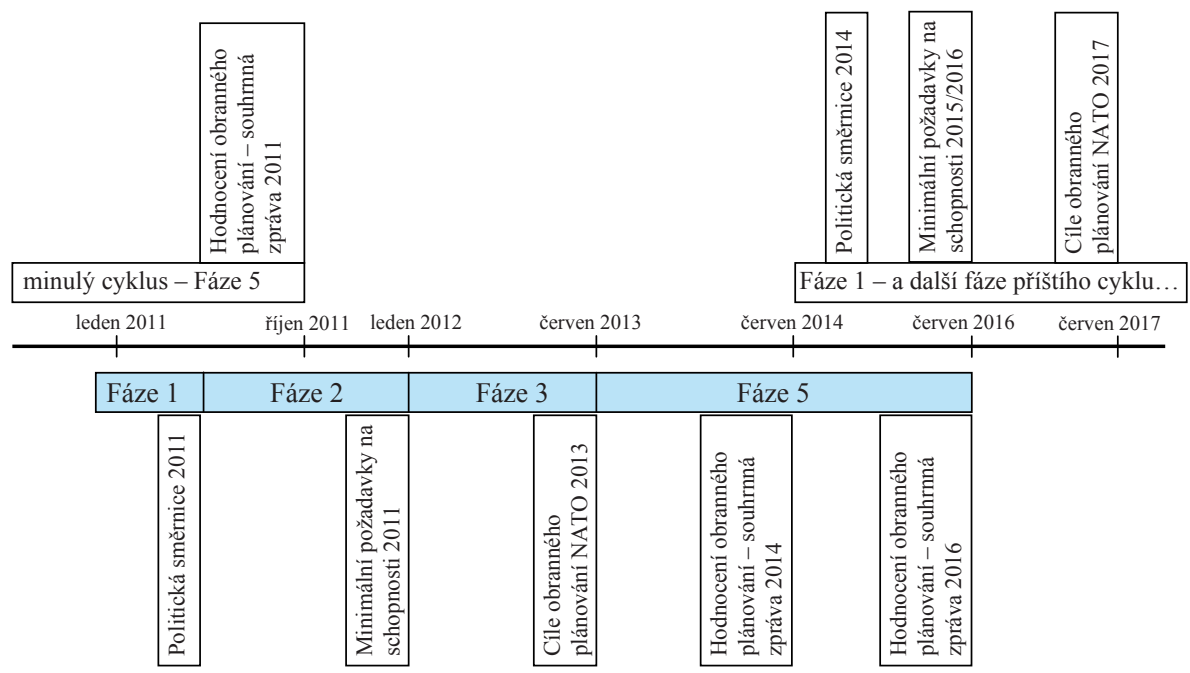

Obr. 2: Schéma současného přechodového cyklu NDPP a jeho klíčové výstupy (proporce časové osy jsou výrazně přizpůsobeny omezenému formátu stránky).

\section{Kontext aktuální diskuze k posílení NDPP}

Summit v Chicagu v květnu 2012 schválil soubor opatření zaměřených na dosažení cíle NATO Forces 2020 (stručně a krátce: interoperabilní síly plně připravené čelit všem aktuálním i potenciálním bezpečnostním výzvám) - dokument nazvaný chicagský obranný balíček. [8]

Součástí chicagského obranného balíčku byl i úkol pro DPPC, aby předložil doporučení ke zlepšení některých aspektů procesu obranného plánování NATO (Enhancing NDPP), zejména: zvýšit relevanci a vliv procesu NDPP na národní procesy plánování, zvýšit viditelnost NDPP pro ministry obrany, zvýšit schopnost procesu reagovat na změny - zejména $\mathrm{v}$ národních plánech či posílit roli NDPP jako nástroje pro včasné konzultace mezi spojenci o zásadních změnách v jejich schopnostech. 
Hlavním účelem tohoto úsilí je zachování věrohodné úlohy NDPP vůči obrannému plánování jednotlivých členských států, z nichž celé řadě se nedostává prostředků ani na prostou reprodukci všech již dosažených schopností a dříve či později byly nuceny přikročit k rušení některých schopností ve svých inventářích - obvykle bez posouzení dopadu na Alianci jako celek. V neposlední řadě by do procesu NDPP měly být začleněny i politicky motivované iniciativy typu Smart Defence či Connected Forces.

Jako jeden z výchozích kroků pro splnění tohoto úkolu (s termínem do zasedání ministrů obrany na jaře 2013) proběhlo ve dnech 25.-26. července 2012 jednání DPPC v posíleném formátu za účasti ředitelů pro obrannou politiku. Výsledkem jednání bylo rozhodnutí zpracovat dvě zprávy pro ministry obrany: první, pro zasedání ministrů v řŕjnu 2012 s doporučeními, jak zvýšit politickou viditelnost výstupů procesu NDPP, druhou zprávu pro únorové zasedání v roce 2013 se zaměřením na úpravy dílčích mechanismů NDPP.

Do samotného zasedání ministrů se text druhé z těchto zpráv nepodařilo odsouhlasit. Po vzájemné dohodě USA a Turecka o posledním sporném bodu zprávy, tedy o způsobu, jak uchopit potenciální zapojení partnerských států do NDPP prostřednictvím projektů Smart Defence, byla zpráva odsouhlasena [9] a vydána jako př́loha k zadání ministrů obrany z jejich zasedání v únoru 2013. [10]

\section{Zvýšení viditelnosti výstupư z NDPP}

Dokument „Improving the Visibility and Relevance of Outputs from the NATO Defence Planning Process““[11] byl schválen na zasedání ministrů obrany v ř́ijnu 2012. Zdůrazňuje potřebu aktivního zapojení ministrů obrany do řešení otázek obranného plánování, jehož účelem je vytvořit takový soubor sil a schopností, s nimiž Aliance bude moci naplnit své ambice. K většímu zapojení politické reprezentace má především pomoci zvýšení viditelnosti výstupů procesu NDPP nejen pro ministry obrany, ale i pro předsedy vlád, hlavy států, ministry financí a volené orgány (parlamenty).

K tomuto účelu by mělo přispět zejména zařazení projednávání plánovacích cílů a hodnocení stavu schopností Aliance mezi standardní témata zasedání ministrů; obsah zpráv by měl být kratší, zaměřený na hlavní problémy, s relevantními návrhy kroků, které by ministři měli podniknout k nápravě př́ípadných problémů. Generální tajemník NATO by měl politickou diskuzi ministrů aktivně podporovat, například svým vlastním hodnocením hlavních problémů ve schopnostech Aliance.

Pozornost ministrů by měla být zaměřena také na problematiku tzv. sdílení břemene. Zejména při schvalování cílů obranného plánování NATO adresovaných jednotlivým státům by dimenze rozložení břemene mezi spojenci měla být ministrům jednoznačně prezentována. K tomu účelu by měly být zvoleny vhodné indikátory, které by ministrům pohotově dokumentovaly aktuální stav a trendy v rozvoji schopností Aliance.

Dále dokument diskutuje a zdůrazňuje význam aktivit mimo své standardní načasování, tzv. out-of-cycle activities. Za ně lze považovat předložení mimořádných zpráv o stavu schopností či provedení konzultací k projednání změn, které určitý stát hodlá provést, a u nichž lze očekávat významný dopad na Alianci jako celek. Tyto konzultace by ideálně měly proběhnout předtím, než členský stát zásadní změny ve struktuře svých schopností - obvykle redukce - provede. 
Z pohledu ČR dokument odpovídá všem jejím dlouhodoběji prosazovaným snahám a zájmům. Politickou viditelnost procesu a závazkủ z něj vyplývajících vnímáme jako základní předpoklad pro fungování NDPP. Aspekty, které je pro zkvalitnění domácí diskuze o obranné politice třeba považovat za zvlášt důležité, tvoří samotné jádro dokumentu - diskuze ministrů nad konkrétními problémy, poskytnutí mandátu generálnímu tajemníkovi vydávat svoje vlastní hodnocení rozvoje schopností pro stimulaci ministerské diskuze, širší využití a distribuce aliančního hodnocení v prostředí domácí politické scény.

\section{Zvýšení relevance a srozumitelnosti NDPP pro národní plánování}

Dvěma dlouhodobě se opakujícími výtkami vůči NDPP jsou a) nedostatečný vliv obranného plánování NATO na individuální národní plány k rozvoji schopností a b) omezená míra transparentnosti, srozumitelnosti a v důsledku toho také věrohodnosti požadavků, které NDPP vůči jednotlivým státům generuje.

Reakcí na první z těchto slabin by mělo být zaměření větší pozornosti NDPP na střednědobý a dlouhodobý plánovací horizont. Lze říci, že v současnosti těžiště NDPP skutečně leží v požadavcích formulovaných pro nejbližších šest let. Řada států proto projevuje zájem o to, aby NATO formulovalo požadavky na schopnosti v horizontu delším, orientačně patnáctiletém, protože pak tyto požadavky budou moci ovlivnit akviziční plány jednotlivých států, což je pro vytváření nových schopností rozhodující. V horizontu kratším než 15 let má řada států své investiční finanční prostředky již vázány na konkrétní akvizice a nemohou tudíž reagovat na případné nové požadavky.

K vytvoření společné alianční představy o budoucím operačním prostředí a schopnostech, které Aliance v dlouhodobém horizontu bude potřebovat, by primárně měly být využity dlouhodobé vize, které si pro obdobný účel zpracovaly jednotlivé členské státy. Přispět by k tomu měla i práce ACT (alianční velitelství pro transformaci) ve formě tzv. Strategic Foresight Analysis. I tento dokument je připravován v součinnosti s členskými zeměmi, do konce září 2013 by měla proběhnout závěrečná úprava textu a jeho publikování. Na něj ACT naváže zpracováním Framework for Future Alliance Operations. NDPP by svým intenzivnějším zaměřením na dlouhodobé plánování a poskytnutím sdílené vize budoucnosti mělo podpořit transformaci sil a schopností spojenců.

Otázka věrohodnosti výstupů NDPP pro národní plánování souvisí zejména s metodou, jak jsou požadavky na celkové schopnosti Aliance stanoveny. Jedná se o náplň druhého kroku NDPP, tedy operačně-analytickou aktivitu nazývanou Capability Requirements Review (CRR), jejímž výsledkem jsou minimální požadavky na schopnosti - NATO Minimum Capability Requirements, (MCR). Spojenci se vesměs shodují, že tento proces je prríliš detailní, proto i přiliš složitý a pracovně velmi náročný, trvá zhruba dva roky. Vzhledem k tomu státy stále nemají reálnou možnost plně nahlédnout vazbu mezi všemi plánovacími předpoklady a výstupy v podobě cílů, které jsou jim adresovány. Na druhou stranu je třeba uznat, že pokud jde o zvýšení transparentnosti procesu stanovení požadavků, v posledních letech odvedla obě strategická velitelství značný kus práce a v rámci každé dílčí fáze mají národní experti možnost seznámit se (formou seminářů) s hlavními aspekty a výstupy jednotlivých kroků. 
Obě strategická velitelství (primárně ACT, které má v této fázi NDPP vedoucí roli) proto provedou reflexi procesu CRR a navrhnou úpravu jeho mechanismů tak, aby potřeba členských států stran plné transparentnosti a srozumitelnosti byla uspokojena. Výsledné úpravy by se měly promítnout již v příštím plánovacím cyklu, jehož výstupem budou cíle obranného plánování 2017. Proces by měl být jednodušší, pracovně a časově méně náročný, a zároveň je nezbytné systémově zajistit, aby MCR zahrnoval všechny požadavky vyplývající ze základních úkolů Aliance (definovaných ve strategické koncepci), a nikoliv jen požadavky vyplývající z politicko-vojenských ambicí (Level of Ambition), které v užším smyslu definují rozsah operací, jež má být Aliance schopna vést.

\section{Konzultace mezi spojenci o změnách plánů}

Důležitým aspektem, na němž je NDPP ve své podstatě založeno, je koordinace příspěvků jednotlivých spojenců k celkovým schopnostem Aliance. Ve chvíli, kdy jedna nebo více členských zemí nekoordinovaně provede významnější změny ve svých schopnostech ve smyslu jejich redukce, je zpochybněna věrohodnost NDPP a jeho výstupů.

Proto jsou spojenci nabádáni k tomu, aby svoje zamýšlené reformy a změny ve svých plánech spolu vzájemně konzultovali, a to předtím, než je provedou. V ideálním případě by daný stát ostatním spojencům avizoval, že se nějaké změny chystá provést, štáby NATO by provedly analýzu dopadů zamýšlených změn na celkové schopnosti Aliance, a navrhly by způsob, jak prrípadně eliminovat potenciální rizika.

Základním smyslem těchto konzultací je vyvarovat se nekoordinovaných škrtů ve schopnostech spojenců, které by mohly vést k oslabení schopností Aliance. V rámci NDPP se nejedná o prvek nový. Je v procesu formálně př́itomen nejméně od roku 1993, idea vzájemných konzultací je přirozeně základním principem budování schopností pro kolektivní obranu. Jeho význam je však nyní zdůrazněn, nebot řada zemí v posledních letech v souvislosti s hospodářskou recesí k redukci svých schopností bez předchozího varování přistoupila. Dopad na alianční schopnosti ve svém důsledku není zanedbatelný a některá rizika týkající se možnosti provedení určitých operací se zvýšila, zejména dále roste závislost Aliance na poskytnutí klíčových schopností USA.

Na skutečnost, že celkem dvanáct spojenců od začátku hospodářské krize provedlo přehodnocení svých schopností, což v řadě případů vedlo ke zrušení významných kapacit v jejich inventářích, a že tyto kroky se odehrály s minimálním či žádným úsilím států o jejich koordinaci spolu s ostatními spojenci, si stěžovala už závěrečná zpráva shrnující závěry hodnocení obranných plánů (Capability Review) z let 2010/2011. [12]

ČR v minulých letech provedla vnitřní racionalizační opatření, jejichž výsledkem vždy byla i určitá redukce kapacit či přímo zrušení některé schopnosti jako takové. Jako poslední př́íklady můžeme uvést Transformaci rezortu MO z roku 2007 a Bílou knihu o obraně z roku 2011. V těchto dvou případech však ČR požádala mezinárodní štáb NATO o doporučení, kde v rámci struktury rezortu MO nejefektivněji dosáhnout úspor a jaké změny ve struktuře zároveň budou či nebudou ku prospěchu Aliance jako celku. Výsledkem těchto doporučení byla například transformace záchranných praporů na prapory ženijní. Tyto konzultace lze považovat za onu předběžnou výměnu informací, k níž jsou v současnosti spojenci vyzýváni, byt’ neproběhly v rámci DPPC a ČR neobdržela reakci prrímo od ostatních členských zemí. V případě, že ČR v budoucnu 
přikročí k dalším změnám ve struktuře rezortu MO, bude žádoucí postupovat důsledně v duchu transparentní konzultace se všemi spojenci.

\section{Zapojení partnerů do projektů Smart Defence a jejich začlenění do NDPP}

Vzájemná souvislost dvou úkolů z chicagského obranného balíčku, tj. prozkoumat modality pro zapojení partnerů do Smart Defence a Connected Forces Initiative, a zároveň navrhnout způsob, jak tento typ iniciativ začlenit do NDPP, byla jedním z kritických míst práce DPPC na zlepšení NDPP (Enhancing NDPP). Hlavním sporem byla otázka, jakým zpo̊sobem uchopit potenciální účast partnerského státu v mnohonárodní schopnosti (např. v projektu Smart Defence), kterou některá alianční země nabídne jako řešení určitého cíle obranného plánování NATO. Partnerem zde rozumíme stát, který spolupracuje s NATO v rámci některého z existujících partnerských formátů - EAPC, MD, ICI, nebo i další státy, spolupracující s NATO na základě jiných specifických dohod. Zde se země neshodly (nejhlasitěji Turecko proti Velké Británii, Německu a Francii), jakým mechanismem může být mnohonárodní schopnost s účastí Partnera v rámci NDPP akceptována, resp. odmítnuta.

S postojem Turecka se v principu shoduje i př́istup ČR, který vychází z toho, že plnění úkolů vyplývajících z NDPP a které směřují mimo jiné k zabezpečení kolektivní obrany, je záležitostí výhradně spojenců. Pokud by některé státy nabízely k plnění cílů NDPP mnohonárodní schopnost, jejíž použití či funkčnost by závisely na zapojení partnera, má kterákoliv členská země právo takovou schopnost odmítnout.

V tomto smyslu je formulován i př́islušný článek (čl. 18) dokumentu o Enhancing NDPP. Výsledný kompromis nad zněním textu byl dosažen až na konci března 2013, zejména po bilaterálních konzultacích mezi Tureckem a USA.

\section{Sdílení břemene a zásada $50 \%$}

Ve snaze o spravedlivější rozložení břemene mezi spojence v poskytování schopností - zvláště těch technologicky vyspělých, velmi nákladných, které také velmi často mají kritický význam pro vedení operací - byla při stanovení cílů obranného plánování NATO, schválených ministry obrany v červnu 2013, poprvé aplikována tak zvaná zásada $50 \%$. V souladu s ní nemá být žádný stát žádán o více než $50 \%$ z celkového požadavku NATO na určitou schopnost. Tento přístup má ulevit USA, které v řadě případů poskytují více než polovinu Aliancí požadovaných kapacit, někdy i $100 \%$.

Byt' ACT a ACO, jako hlavní orgány odpovědné za stanovení aliančních požadavků a rozvržení cílů mezi členské státy, nedostaly žádný politický pokyn toto pravidlo aplikovat, a ani sama „zásada 50\%“ nemá oporu v žádné politické dohodě členských států, USA její uplatnění v tomto plánovacím cyklu (CRR 2012, Targets 2013) vítají a plně podporují. Ve svém důsledku by ve střednědobém horizontu (kolem roku 2020) měla být významná část břemene spočívající v poskytování některých kritických schopností přenesena z USA na ostatní státy.

Terminologická poznámka na okraj: V průběhu diskuzí o povaze této zásady, zejména s ohledem na to, aby bylo zřejmé, že se nejedná o spojenci schválené pravidlo, 
dospěl DPPC $k$ dohodě, že se pro toto kritérium bude používat termín „plánovací predpoklad“.

Zda je právě taková zásada nejvhodnějším způsobem, jak dospět ke spravedlivému sdílení břemene, je širší a bytostně politickou otázkou. Zejména Německo se již v rámci multilaterálního jednání DPPC (květen 2013) k finalizaci svých cílů vyjádřilo v tom smyslu, že univerzální použití ,zásady 50\%“ nepovažuje za racionální, protože v některých případech jsou tak na některé státy kladeny (finančně) velmi náročné požadavky, které v podstatě nepřispívají k odstranění reálného nedostatku ve schopnostech Aliance, ale pouze $\mathrm{k}$ přesunutí většího břemene v poskytování schopností na jiné státy než USA.

Především mělo na mysli konkrétní příklad tankerů pro doplňování paliva za letu, kdy NATO potřebuje cca 235 tankerů, a USA disponují zhruba 470 tankery. Argumentace Německa je taková, že místo toho, aby od některých států bylo požadováno pořízení tankerů v počtech, pro něž ani nemají uplatnění, bylo by prospěšnější, aby své prostředky investovaly na akvizici schopností, kterých se Alianci skutečně nedostává. Stejnou pozici při zasedání ministrů obrany v červnu 2013 vyjádřily i Polsko a Estonsko. Francie, Velká Británie a např. Turecko v zásadě uznávají potřebu snížit závislost Aliance na USA, nejsou však přesvědčeny, že problém a jeho řešení lze redukovat do tak jednoduché zásady, jak je v tuto chvíli prezentováno pravidlo či zásada $50 \%$. Celá řada zemí zároveň poukazuje na druhou stranu mince, a tou je evropská dimenze sdílení břemene. Také mezi evropskými zeměmi panuje v poskytování schopností nevyváženost, ale na rozdíl od té transatlantické zatím nebyla předmětem strukturované diskuze.

\section{Závěrem}

Proces obranného plánování NATO je živým a vyvíjejícím se nástrojem a tento rys si velmi pravděpodobně zachová i do budoucna. NDPP zůstane jedním z páteřních procesů v Alianci. Problémy, resp. výzvy, s nimiž se NDPP v současnosti potýká, nejsou zcela nové, a historická zkušenost napovídá, že je zřejmě neřeší ani naposled. Vzhledem k základním premisám strategie obrany ČR je důležité, aby výstupy NDPP i nadále byly tím hlavním vstupem udávajícím zaměření a cíle pro rozvoj schopností systému obrany ČR. Je zapotřebí, aby na základě tohoto východiska součásti rezortu MO odpovědné za obranné plánování jednaly a vedly interakci s procesem NDPP takovým způsobem, aby na národní úrovni dosáhly vyváženého systému plánování s vysokou mírou vnitřní konzistence, pokud jde o samotný obsah plánů a politicky stanovených ambicí.

Prakticky to neznamená nic jiného než vytvoření dlouhodobě stabilní, tj. realistické vize budoucích ozbrojených sil, včetně transparentní deklarace politických ambicí pro jejich použití. Cesta k naplnění vize pak vede přes střednědobé plánování. A opět není překvapením, že jen realisticky a s ohledem na dlouhodobější priority zpracovaný střednědobý plán může splnit svou roli. Bez něj také veškeré závazky ke splnění cílů obranného plánování NATO zůstanou jen prázdnými proklamacemi.

V prostředí rezortu MO je střednědobý plán jediným vhodným nástrojem pro posouzení, které cíle obranného plánování NATO, v jakém rozsahu a v jakých termínech budou realizovatelné. Pokud náš rezortní střednědobý plán není schopen poskytnout odpověd' na tyto otázky, např́klad proto, že formát, obsah či úroveň detailu aliančních cílů nejsou vzájemně porovnatelné s obsahem střednědobého plánu, je třeba uvažovat 
o změně. Možnosti jsou v zásadě dvě - bud' změnit obsahovou strukturu střednědobého plánu, nebo usilovat o změnu zpo̊sobu, jakým jsou formulovány cíle obranného plánování NATO. Obojí je možné, a například na straně mezinárodního štábu NATO je vůle zásadním způsobem omezit míru detailu, kterou alianční cíle v současnosti obsahují.

\section{Poznámky k textu a literatura:}

[1] Pro porovnání celkového rozsahu, obsahu a zaměření současné iniciativy s jednou z minulých významnějších vln reflexe a optimalizace aliančního procesu obranného plánování viz HRADIL, Stanislav - PROCHÁZKA, Josef. Alianční plánování - stav, vývoj a jeho harmonizace s národními postupy. Obrana a strategie, roč. 2004, č. 2, str. 91-104. Dostupné též na www.defenceandstrategy.eu.

[2] Tento článek reflektuje vývoj v posledních dvou letech včetně závěrů ze zasedání ministrů obrany v červnu 2013.

[3] Outline Model for a NATO Defence Planning Process, PO(2009)0042, popisuje proces NDPP obecně, přesto však relativně podrobně. Některé aspekty procesního modelu NDPP však budou v praxi novelizovány dokumentem Enhancing the NATO Defence Planning Process, AC/281-N(2012)0154-REV9 (R), jehož finální podoba byla odsouhlasena Severoatlantickou radou dne 27. března 2013. O jeho hlavních rysech viz další dvě kapitoly.

[4] Political Guidance, C-M(2011)0022, 14. 3. 2011.

[5] NATO’s Minimum Capability Requirements 2011, AC/281-N(2012)0003 (R), 4. 1. 2012.

[6] Synopsis of the 2011. Minimum Capability Requirements and Summary of the 2012 Priority Shortfall Areas, AC/281-N(2012)0063 (R), 2. 4.2012 (vlastní materiál) a AC/281-N(2012)0130-AS1 (R), 17. 9. 2012 (usnesení DPPC).

[7] NATO Capability Targets 2013, C-M(2013)0023, 30. 5. 2013.

[8] Defence Package, PO(2012)0229, 19. 5. 2012.

[9] Enhancing the NATO Defence Planning Process, AC/281-N(2012)0154-REV9 (R), 12. 3. 2013.

[10] Proposed Follow-on Taskings from the Defence Ministerial Guidance, PO(2013)0119-REV3, 21. 3. 2013.

[11] Improving the Visibility and Relevance of Outputs from the NATO Defence Planning Process, $\mathrm{PO}(2012) 0437,8.10 .2012$.

[12] NATO Defence Planning Capability Review, 2010/2011 - Defence Planning Capability Report, C-M(2011)0069, 3. 10. 2011.

Přehled použitých zkratek

\begin{tabular}{lll}
\hline ACO & Allied Command Operations & Spojenecké velitelství pro operace \\
\hline ACT & Allied Command Transformation & Spojenecké velitelství pro transformaci \\
\hline CRR & Capability Requirements Review & přehodnocení požadavků na schopnosti \\
\hline DPPC & Defence Policy and Planning Committee & výbor pro obrannou politiku a plánování \\
\hline EAPC & Euro-Atlantic Partnership Council & Euroatlantická rada partnerství \\
\hline ICI & Istanbul Cooperation Initiative & Istanbulská kooperační iniciativa (státy ICI) \\
\hline MCR & Minimum Capability Requirements & minimální požadavky na schopnosti NATO \\
\hline MD & Mediterranean Dialogue & Středomořský dialog (státy MD) \\
\hline NDPCS & $\begin{array}{l}\text { NATO Defence Planning Capability } \\
\text { Survey }\end{array}$ & dotazník obranného plánování \\
\hline NDPP & NATO Defence Planning Process & proces obranného plánování NATO \\
\hline NDPST & NATO Defence Planning Staff Team & společný plánovací tým NATO \\
\hline RPPB & Resource Policy and Planning Board & výbor pro politiku a plánování zdrojů \\
\hline
\end{tabular}

